\title{
Detection of Early Pregnancy Factor in Superovulated Mice
}

\author{
Yoshiyuki TAKIMOTO, Mitsugu HISHINUMA, Yoshiyuki TAKAHASHI, and Hiroshi KANA- \\ GAWA \\ Department of Theriogenology, Faculty of Veterinary Medicine, Hokkaido University, Sapporo 060, Japan
}

(Received 15 November 1988/Accepted 1 June 1989)

\begin{abstract}
Rosette inhibition tests for the detection of early pregnancy factor (EPF) were performed on naturally ovulated and superovulated mice from day 2 of pregnancy up to 4 days after parturition. In both groups of mice, the rosette inhibition titre (RIT) increased on day 2 of pregnancy, and persisted at high levels until day 15 . Thereafter, the RITs of both groups of mice decreased to the non-pregnancy range. No significant differences of the mean RITs between these two groups were observed during the high RIT period. These results showed that the superovulatory treatment did not cause any changes or interference in the detection of EPF. In order to investigate the initial time of appearance of EPF in the maternal circulation in relation to the stage of fertilization, measurement of RIT and examination of the fertilization stage were carried out on superovulated mice 1 day after mating. The mean RIT of mice with pronucleus stage ova was significantly $(\mathrm{p}<0.01)$ higher than that of mice with spermpenetrated ova. EPF was considered to appear in the maternal peripheral blood at the pronucleus stage.-KEY wORDS: early pregnancy factor, mouse, superovulation.
\end{abstract}

Jpn. J. Vet. Sci. 51(5): 879-885, 1989

Immunological rejection of fetal tissue, considered to be an allograft, normally does not occur in the maternal uterus. The mechanism of this phenomenon is currently under investigation. Early pregnancy factor (EPF) was first reported by Morton et al. [10] and is considered to be one of the immunosuppressive factors during pregnancy. Some immunosuppressive abilities of EPF have been demonstrated $[1,4,5,10$, $11]$, but they are only indirectly related to the maternal immune tolerance during pregnancy.

Human chorionic gonadotrophin (HCG), which is also considered as an immunosuppressive factor [18], has been demonstrated to contain EPF in its crude preparation [8, $16,22]$ and to have immunological crossreactivity with EPF [13]. Therefore, it is suggested that HCG therapy affects the detection of EPF. It is reported in rats that superovulatory treatment with pregnant mare serum gonadotrophin (PMSG) and
HCG inhibited subsequent fetal implantations, thus resulting in the disappearance of EPF [23]. However the effect of superovulatory treatment on the changes in the activity of EPF after implantation with the condition that embryonic death does not occur is still unknown.

In addition, EPF is detectable at a very early stage of pregnancy, $6 \mathrm{hr}$ after mating in mice [11], and reflects embryonic existence $[3,6,8,15,20,21,23]$, thus attracting attention as a new method for monitoring embryos. In some species, the initial time when EPF could be detected in relation to the time after mating has been found out [3, $6-8,12]$; however, the time in relation to the stage of fertilization has not been reported.

The objectives of the present study were firstly to examine the effect of superovulatory treatment on the changes in the activity of EPF during subsequent pregnancy, and secondly to investigate the time when EPF appears in the maternal peripheral blood in relation to the stage of fertilization. 


\section{MATERIALS AND METHODS}

Mice: Male $\mathrm{C} 3 \mathrm{H} / \mathrm{He}$ strain mice, aged 6-12 weeks, were used as donors of spleen cells in the rosette inhibition tests. Female ddY strain mice, aged 5-20 weeks, were used as donors of test sera. Male mice of the same strain and age were used for mating. All mice were maintained under controlled lighting (14 hr light and $10 \mathrm{hr}$ dark; light on at 5 a.m.).

Estrous Cycle: Vaginal smears from female mice were examined daily to classify the estrous cycle; proestrus, estrus, metestrus or diestrus.

Natural Mating: One female at proestrus was paired with one male and caged overnight. The female was checked for the presence of a vaginal plug the next morning. The day on which the vaginal plug was found was designated as day 1 of pregnancy.

Induction of Pseudopregnancy: Groups of two females were caged with one vasectomized male, and the females were checked every morning for the presence of vaginal plugs (=day 1 of pseudopregnancy).

Superovulatory Treatment: Female mice were induced to superovulate by an intraperitoneal injection of 5 I.U. PMSG (Serotropin; Teikoku Zouki, Japan), followed by an injection of 5 I.U. HCG (Gonatropin; Teikoku Zouki, Japan) 48 hr later. After $\mathrm{HCG}$ injection, the treated mice were mated as described above.

Serum Samples: Mice were bled by cardiac puncture under ether anaesthesia. Blood was allowed to clot at room temperature before centrifugation at $1,600 \times \mathrm{g}$ for 10 min. Serum was removed, inactivated at $56^{\circ} \mathrm{C}$ for $30 \mathrm{~min}$, then frozen and stored at $-20^{\circ} \mathrm{C}$.

Confirmation of Pregnancy and Parturition: The presence of embryos in the oviduct or uterus during days $2-5$, or fetal tissues in the uterus during days $7-20$ of pregnancy was taken as the evidence of pregnancy. Sera from mice that did not show the pregnant evidence after mating with fertile males were discarded. As for parturition, the mice were checked every morning for neonates (=day 1 of parturition).

Detection of EPF: For the detection of the activity of EPF, the rosette inhibition test was used. A summary of the procedure is presented in Fig. 1.

Spleen cell suspensions were prepared in $\mathrm{Ca}^{2+}-\mathrm{Mg}^{2+}$-free Hanks' balanced salt solution (HBSS) from the spleens of male $\mathrm{C} 3 \mathrm{H} / \mathrm{He}$ mice. After removal of the red blood cells (RBCs) and three washes in HBSS, the concentration of the suspension was adjusted to $1.0 \times 10^{7}$ cells $/ \mathrm{m} l$. Then 1.5 $\mathrm{m} l$ aliquots of the suspension were centrifuged at $200 \times \mathrm{g}$ for $5 \mathrm{~min}$ and, after aspiration of the supernatant, the cell pellets were resuspended in $1.0 \mathrm{~m} l$ of a test serum sample

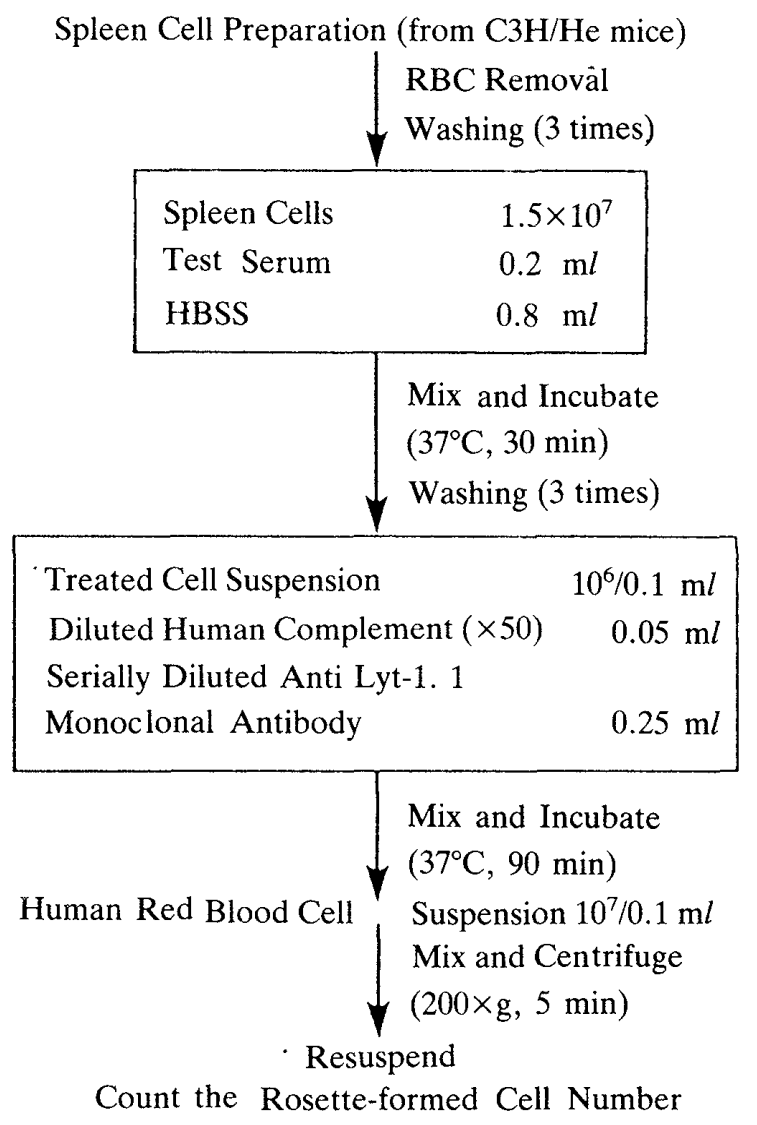

Fig. 1. Procedure of the rosette inhibition test. 
diluted 1:4 in HBSS. After incubation at $37^{\circ} \mathrm{C}$ for $30 \mathrm{~min}$, the cells were washed three times and resuspended in a final volume of $1.5 \mathrm{~m} l$.

For anti-lymphocyte sera (ALS), the preparation of monoclonal antibodies (AntiMouse Lyt-1.1 Monoclonal Antibody; Cedarlane, USA) was diluted to 1 in $10^{3}$ in HBSS, followed by serial dilution to 1 in $2^{10} \times 10^{3}$, making 11 tubes containing $0.25 \mathrm{ml}$ of one of the dilutions and one tube containing $0.25 \mathrm{~m} l$ of HBSS (control). Then $0.1 \mathrm{~m} l$ of spleen cell suspension and $0.05 \mathrm{ml}$ of 1-in-50 diluted human serum (source of complement) were added to each of the tubes, which were incubated at $37^{\circ} \mathrm{C}$ for 90 min. After incubation, the tubes were placed at room temperature for $10 \mathrm{~min}$. Next, $0.1 \mathrm{~m} l$ of human RBC suspension, adjusted to $1.0 \times 10^{8}$ cells $/ \mathrm{ml}$, was added to each of the tubes, which were immediately centrifuged at $200 \times \mathrm{g}$ for $5 \mathrm{~min}$, producing rosette formations. Human RBC suspension was prepared daily from the same donor who provided the human sera.

After centrifugation, the pellets were gently resuspended. One drop of each suspension was then spread on a glass slide with brilliant cresyl blue. The mean number of rosettes per 100 cells in each tube was calculated by the microscopic observation of more than 500 mononuclear cells. Then the results of each dilution of ALS were expressed as a percentage of the non-inhibited rosette formation (the control tube in which $0.25 \mathrm{~m} l$ HBSS without ALS was added).

The activity of EPF in the sample serum was expressed as the rosette inhibition titre (RIT) [13], which is defined as the highest dilution of ALS in which the rosette formation is less than $75 \%$ of the number formed in the control tube. The RIT was expressed as the logarithm (to base 2) of the reciprocal dilution of ALS $\times 10^{-3}$.

Statistical Analysis: Differences betwen individual means of RITs were tested by
Student's $t$-test.

Experiment I, Effect of Superovulatory treatment on the changes in the activity of $E P F$ : First, in order to determine the EPF-negative RIT ranges, RITs of the sera from nonpregnant and pseudopregnant mice that were known to be EPF negative $[3,11-15,21]$ were measured using the assay system described above. Serum samples were collected and rosette inhibition tests were carried out at each stage of the estrous cycles and at days 2, 3, 5, 7, 10 and 15 of pseudopregnancy.

Second, in order to examine the effect of superovulatory treatment, the changes in the activity of EPF during pregnancy and post parturition were compared between naturally ovulated and superovulated pregnant mice. Collection of serum samples and rosette inhibition tests were performed at days $2,3,5,7,10,13,15,18$ and 20 of pregnancy and days 2 and 4 of parturition.

Experiment II, Detection of EPF in relation to the stage of fertilization: Superovulated pregnant mice were bled and ova collections were immediately carried out from 5 a.m. to 9 p.m. of day 1 of pregnancy. Rosette inhibition tests were done on the collected serum samples. The oviducts were removed and flushed with Dulbecco's phosphate-buffered saline (PBS). The ova from each mouse were fixed and stained with aceto-lacmoid. If cumulus cells surrounded the ova, they were removed by $0.1 \%$ hyaluronidase treatment before fixation. Under phase contrast microscopy, the ova were examined for the stage of fertilization and mice were classified into 4 groups as described below.

Group 1: Mice having unfertilized ova with spermatozoa.

Group 2: Mice having fertilized ova in which an enlarged sperm head is observed.

Group 3: Mice having fertilized ova in which the male pronucleus or the fusion 
of male and female pronuclei was observed.

Group 4: Mice having 2-cell stage embryos.

The mean RIT of each group was compared.

\section{RESULTS}

Experiment I: Figures 2 and 3 show the results of the RIT measurements of nonpregnant and pseudopregnant mice, respectively, known to be EPF negative. The mean RIT of nonpregnant mice was 2.1. The mean RITs of the proestrous, estrous, metestrous and diestrous stages were 2.3,

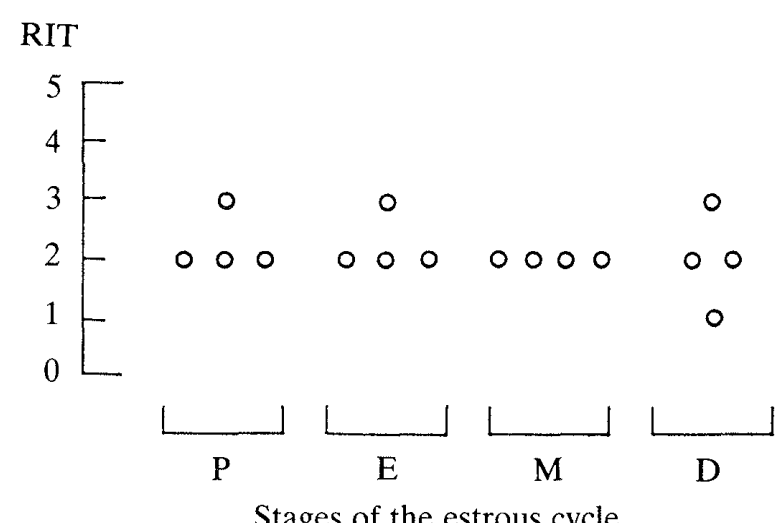

Fig. 2. RTT changes in the estrous cycles: proestrus $(\mathrm{P})$, estrus $(\mathrm{E})$, metestrus $(\mathrm{M})$ and diestrus (D).
2.3, 2.0 and 2.0, respectively, showing no differences among the values during the estrous cycle. The mean RIT of pesudopregnant mice was 1.9 , showing no change in relation to pseudopregnancy. The serum RITs of nonpregnant and pseudopregnant mice ranged from 1 to 3 .

Figure 4 shows the results of the RIT measurements of naturally ovulated and superovulated pregnant mice. On day 2 of pregnancy, the mean RITs of naturally ovulated and superovulated mice were 4.0 and 5.3, respectively, showing significantly higher values than those of control, nonpregnant and pseudopregnant mice $(\mathrm{p}<0.01)$. During the high RIT period, which was maintained to day 15 of pregnan-

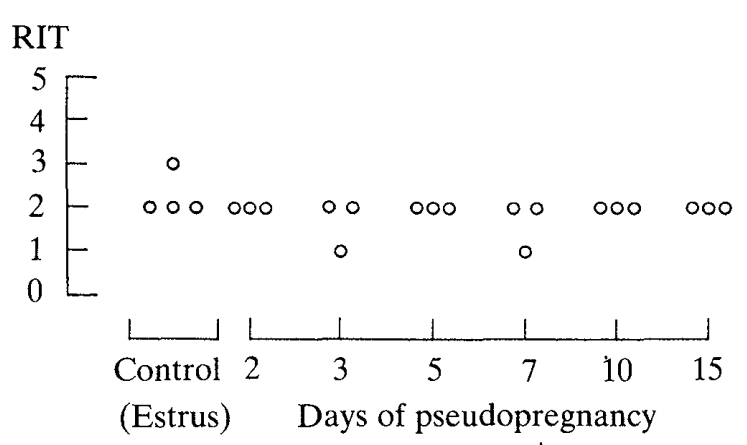

Fig. 3. RIT changes during pseudopregnancy.

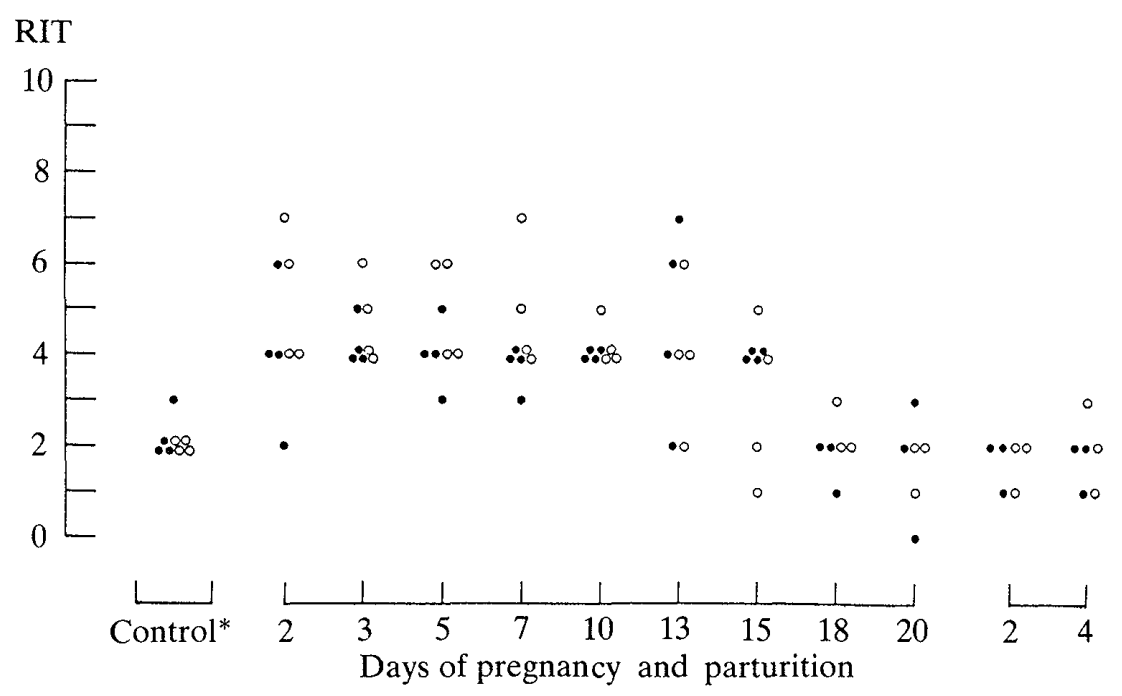

Fig. 4. RIT changes of naturally ovulated and superovulated mice from day 2 of pregnancy up to day 4 of parturition. A naturally ovulated mouse. $\bigcirc$ : A superovulated mouse. *: Day 2 of pseudopregnancy. 


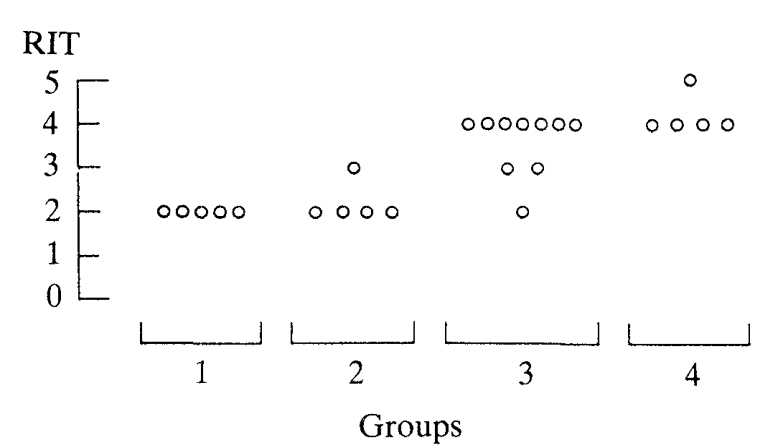

Fig. 5. RIT changes in relation to the fertilization stage. Groups: see text.

cy, the mean RIT of superovulated mice (4.4) was slightly but non-significantly higher than that of naturally ovulated mice (4.1). Thereafter, mean RITs of naturally ovulated and superovulated mice decreased to 1.7 and 1.9 , respectively.

Experiment II: Figure 5 shows the results of the RIT measurements of Groups 1 to 4 . Mean RITs of Group 1, with no fertilized ova, and Group 2, with sperm-penetrated ova, were 2.0 and 2.2 , respectively. All RITs were 3 or lower. In contrast, mean RITs of Group 3, with male pronucleusformed ova and Group 4, with 2-cell stage embryos, were 3.6 and 4.2 , respectively, thus showing significantly higher values than those of Groups 1 and $2(\mathrm{p}<0.01)$. Though the mean RIT of Group 4 was slightly higher than that of Group 3, no significant difference was detected.

\section{DISCUSSION}

The existence of an embryo and/or fetus is considered essential to the appearance of EPF in the maternal circulation. Furthermore, during nonpregnancy or pseudopregnancy EPF was absent in mice [11, 14], women $[3,13,20]$ and sheep $[12,15]$. The present study also showed no increase in RIT in mice during nonpregnancy and pseudopregnancy. RITs of nonpregnant and pseudopregnant mice, which are considered to be EPF negative, ranged from 1 to 3 . Thus, it would seem reasonable that in our assay system RIT ranges of EPF-negative were 3 or lower and that positive ranges were 4 or higher.

In most species, it is known that EPF, which is detectable in early period after a fertile mating, disappears from the maternal circulation during the second half of pregnancy $[7,9-11,13]$. It is reported in the mouse that EPF can not be detected on day 15 of pregnancy $[7,11]$. Conversely, the present study showed that the RITs of pregnant mice persisted at high levels until day 15. This difference is considered to be due to the different mouse strains used for spleen cells $(\mathrm{C} 3 \mathrm{H} / \mathrm{He})$ and test sera (ddY), the technical differences in the details of the rosette inhibition test and the variations of individual mice, as described by Morton [9]. In order to identify the disappearanceperiod of EPF, daily detections of EPF of the same mouse from days 13 to 18 of pregnancy are necessary.

The present study shows no significant difference in RIT between naturally ovulated and superovulated pregnant mice. Both preparations of HCG and PMSG, used for the superovulatory treatment, are derived from pregnant animals. It was reported that HCG has some immunosuppressive activities [18] and has immunological cross-reactivity with mouse EPF [4]. Furthermore, EPF activities are present in the HCG preparations $[8,16]$. PMSG is also known to exist in the circulation several days after injection [17], and the possible existence of EPF contaminants in the PMSG preparations is suggested. Nevertheless, the results of this study showed that the hormones and their immunosuppressive contaminants in the administered preparations have no effect on the changes in the activity of EPF. In addition, Yasuda et al. [23] reported that EPF could be detected on day 1 of pregnancy from rats which were injected with PMSG and HCG. The result of this study showed that the RITs of the 
superovulated pseudopregnant mice, used as a control, were in EPF-negative ranges. The EPF contaminants from the preparation probably bind to lymphocytes and thus free EPF molecules in the circulatioin disappear [5, 9]. Hence hormone treatments, which might contain EPF contaminants, have no effect on the detection of EPF.

The results of Experiment II show the relationship between the appearance of EPF and the fertilization stage; EPF in the serum is detectable at the pronucleus stage, but not at the sperm-penetration stage. In mice, it was suggested that EPF would appear at the pronucleus stage since serum EPF could be detected 4-6 hr after mating [11]. The present results confirmed the suggestion. In Experiment II, 3 of 10 mice with pronuclei stage ova (Group 2) were EPF negative, while all mice with 2-cell stage embryos (Group 4) were EPF positive. Cavanagh [2] reported an ovum factor, which is released from the mouse ovum upon sperm penetration and signals the appearance of detectable EPF in the maternal circulation. One of the possible reasons for the appearance of EPF-negative mice in Group 3 might be individual variations in the time it would take for detectable EPF to appear in response to the ovum factor.

Though embryonic abilities to secrete ovum factor [2] and EPF [7, 19, 21] were discovered, the mechanism in which how an early embryo cooperates with the maternal body in producing EPF has not been elucidated. It is only suggested that ovary and oviduct produce EPF in response to the embryonic signals [14].

\section{REFERENCES}

1. Bordekar, A. D., Mehta, A. R., Moulik, S., Moodbidri, S. B., and Shahani, S. K. 1987. Evaluation of immunosuppressive property of partially purified early pregnancy factor from human pregnancy serum by an in vivo immunobioassay. Ind. J. Exp. Biol. 25: 487-488.
2. Cavanagh, A. C., Morton, H., Rolfe, B. E., and Gidley-Baird, A. A. 1982. Ovum factor: a first signal of pregnancy. Am. J. Reprod. Immunol. 2: 97-101.

3. Chen, C., Jones, W. R., Bastin, F., and Forde, C. 1985. Monitoring embryos after in vitro fertilization using early pregnancy factor. pp. 420-428. In: In Vitro Fertilization and Embryo Transfer, Ann. NY. Acad. Sci. 442 (Seppala, M. and Edwards, R. G. eds.), NY Acad. Sci., NY.

4. Clarke, F. M., Morton, H., and Clunie, G. J. A. 1978. Detection and separation of two serum factors responsible for depression of lymphocyte activity in pregnancy. Clin. Exp. Immunol. 32: 318-323.

5. Cocchiara, R., Trapani, G. D., Azzolina, A., Cittadini, E., and Geraci, D. 1986. Binding of human EPF to receptors on PMBC as a first signal of pregnancy immunomodulation. Hum. Reprod. 1: 33-36.

6. Georgieva, R. and Stefanov, D. 1984. Early pregnancy factor (EPF) in cows and sows. Detection of pregnancy, embryonic mortality and its partial characterization. Proc. 10th Intern. Congr. Anim. Reprod. \& AI. (Illinois) 2: 83-84.

7. Igarashi, S. 1984. Studies of early pregnancy factor by rosette inhibition test using monoclonal antibody. Acta Obst. Gynaec. Jpn. 36: 519-524.

8. Igarashi S. 1986. Clinical significance of early pregnancy factor. Acta. Obst. Gynaec. Jpn. 38: 896-902 (in Japanese with English abstract).

9. Morton, H. 1984. Early Pregnancy factor (EPF): a link between fertilization and immunomodulation. Aust. J. Biol. Sci. 37: 393-407.

10. Morton, H., Hegh, V., and Clunie, G. J. A. 1974. Immunosuppression detected in pregnant mice by rosette inhibition test. Nature (Lond.) 249: 495-460.

11. Morton, H., Hegh, V., and Clunie, G. J. A. 1976. Studies of the rosette inhibition test in pregnant mice: evidence of immunosuppression. Proc. $R$. Soc. Lond. B. 193: 413-419.

12. Morton, H., Nancarrow, C. D., Scaramuzzi, R. J., Evison, B. M., and Clunie, G. J. A. 1979. Detection of early pregnancy in sheep by the rosette inhibition test. J. Reprod. Fertil. 56: $75-80$.

13. Morton, H., Rolfe, B. E., and Clunie, G. J. A. 1977. An early pregnancy factor detected in human serum by the rosette inhibition test. Lancet 19: 394-397.

14. Morton, H., Rolfe, B. E., McNeill, L., Clarke, P., Clarke, F. M., and Clunie, G. J. A. 1980. Early pregnancy factor: tissues involved in its production in the mouse. J. Reprod. Immunol. 2: 73-82.

15. Nancarrow, C. D., Evison, B. M., Scaramuzzi, R. 
J., and Turnbull, K. E. 1979. Detection of induced death of embryos in sheep by the rosette inhibition test. J. Reprod. Fertil. 57: 385-389.

16. Rolfe, B. E., Morton, H., and Clarke, F. M. 1983. Early pregnancy factor is an immunosuppressive contaminant of commercial preparations of human chorionic gonadotrophin. Clin. Exp. Immunol. 51: 45-52.

17. Sasamoto, S., Sato, K., and Naito, H. 1972. Biological active life of PMSG in mice with special reference to follicular ability to ovulate. J. Reprod. Fertil. 30: 371-379.

18. Siiteri, P. and Stites, D. P. 1982. Immunologic and endocrine interrelationships in pregnancy. Biol. Reprod. 26: 1-14.

19. Smart, Y. C., Cripps, A. W., Clancy, R. L., Roberts, T. K., Lopata, A., and Shutte, D. A. 1981. Detection of an immunosuppressive factor in human preimplantation embryo cultures. Med.
J. Aust. 1: 78-79.

20. Smart, Y. C., Fraser, I. S., Clancy, R. L., Roberts, T. K., and Cripps, A. W. 1982. Early pregnancy factor as a monitor for fertilization in women wearing intrauterine devices. Fertil. Steril. 37: 201-204.

21. Sueoka, K. 1985. Study on early pregnancy factor; concerning on human in vitro fertilization and embryo transfer. Jpn. J. Fertil. Steril. 30: 403-410 (in Japanese with English abstract).

22. Sueoka, K., Ito, K., Miyazaki, T., Natori, M., Morisada, M., and Kobayashi, T. 1987. Biochemical consideration of early pregnancy factor (EPF). J. Fertil. Implant. (Tokyo) 4: 24-28.

23. Yasuda, Y., Miyazaki, A., and Takahashi, J. 1988. Detection of early pregnancy factor (EPF) in rats and its physiological characteristics. J. Fac. Agr. Iwate Univ. 19: 21-35 (in Japanese with English abstract).

要 約

過㮃排卵処置マウスからの早期妊娠因子の検出：瀧本良幸・菱沼 貢 ·高橋芳幸・金川弘司 (北海道大学獣医 学部家畜臨床繁殖学講座)——ウスの早期妊娠因子 (EPF) 検出に及ぼす過剩排卵処置の影響を調べるために, 自然排卵拉よび過剩排卵マウスについて妊娠中のロゼット抑制力価(RIT)の変動を比較した。 どちらのマウスで も，妊娠 2 日目にはRITが上昇しており，妊娠15日目までその值は維持された。 その後，RITは非妊娠域まで 低下し，再び上暴することはなかった。妊娠 2 1 15 日目までの期間の平均 RITについて，自然排卯拉よび過剩 排卵マウス間で有意差は認められなかった。これらの結果から，過剩排卵処置がその後の妊娠中のEPF検出お よびその消長に及ぼす影響はないと考えられた。次いで，受精の進行状態と EPF 出現時期との関係を調べるた めに，妊娠 1 日目の過剩排卵マウスについてRITの測定と卵子の検查を行った。その結果，前核期卵子を有す るマウスのRIT は精子侵入卵子を有するマウスのRITに対して有意に高い值を示した $(\mathrm{p}<0.01)$. よって EPF は交配後，前核期より母体血中に出現すると考えられた。 